\title{
STRUCTURAL DEFORMATION OF THE IDAHO-WYOMING OVERTHRUST BELT (U.S.A.), AS DETERMINED BY TRIASSIC PALEOMAGNETISM
}

\author{
K.L. GRUBBS and R. VAN DER VOO \\ Department of Geology and Mineralogy, The University of Michigan, Ann Arbor, \\ Michigan (U.S.A.)
}

(Accepted for publication March 15, 1976)

\begin{abstract}
Grubbs, K.L. and Van der Voo, R., 1976. Structural deformation of the Idaho-Wyoming overthrust belt (U.S.A.), as determined by Triassic paleomagnetism. In: J.C. Briden (editor), Ancient Plate Margins, Tectonophysics, 33: 321-336.
\end{abstract}

A paleomagnetic study of Triassic redbeds from fourteen sites within the IdahoWyoming overthrust belt and three sites from the adjacent stable foreland was undertaken in an attempt to decipher the origin of the arcuate shape of the thrust-fold belt in northwestern Wyoming. This belt rises from beneath the Snake River lava plain in eastern Idaho and trends east-southeast into Wyoming. South of Jackson, Wyoming, the belt swings 45 to 70 degrees to trend almost due south into west-central Wyoming.

A total of 193 samples were paleomagnetically analyzed using spinner and cryogenic magnetome ters. Thermal demagnetization up to $681^{\circ} \mathrm{C}$ reveals that the natural remanent magnetization consists characteristically of two directional components. A small secondary (chemical) magnetization is revealed at temperatures below $500^{\circ} \mathrm{C}$, whereas a proportionally large characteristic magnetization appears to be primary and conforms to the expected Triassic latitudes of the North American craton. The site-mean directions have Fisher precision $k$ ranging from 14 to 149 , with confidence cones of $95 \%$-probability ranging between $4.8^{\circ}$ and $16.2^{\circ}$. The characteristic (primary) directions of magnetization indicate that the structural bend in the overthrust belt originated through tectonic rotations of the thrust sheets in the horizontal plane, as the paleomagnetic declinations show a systematic change corresponding to the structural configuration mentioned above.

We propose that as overthrusting progressed from west to east in the Late Mesozoic and Early Tertiary, the thrust sheets experienced an increasing resistance to movement due to the proximity of the ancient arcuate foreland margin. The buttressing effect of the foreland hinge on the overthrust plates caused the frontal edges of the thrusts to assume the configuration of the foreland margin resulting in horizontal rotations of the thrust sheets. The easternmost Prospect-Cliff Creek-Jackson thrust sheet came into actual contact with the ancestral Teton-Gros Ventre Precambrian block on the north and the Game Hill reverse fault on the east; as a result the northern sections of the thrust sheet rotated by an amount of up to 60 degrees in a counter-clockwise sense and the southern and eastem sections rotated in a clockwise direction by an amount of up to 30 degrees. 


\section{INTRODUCTION}

The Idaho-Wyoming overthrust belt forms part of a zone of Laramide deformation along the ancient western margin of the North American craton. The thrust-fold belt rises from beneath the Snake River lava plain in eastern Idaho and trends east-southeastward into Wyoming. In the vicinity of Jackson, Wyoming, the structural trends make an abrupt bend through 45 to 70 degrees to run approximately north-south into west-central Wyoming (Fig. 1).

Though the mode of overthrust emplacement and the origin of the arcuate bend in this area have been the focus of previous studies, we felt that a paleomagnetic investigation could provide valuable evidence on the origin of the curvature and give some hint as to the mechanism of overthrust emplacement. The Triassic redbeds that occur abundantly in the Laramide thrust sheets appeared ideal for a paleomagnetic study of this nature; in addition they are widespread on the adjacent stable craton. Precise age determinations for the individual units within the sequence of red sediments are less ideal. The stratigraphically lower red sediments (the Woodside Formation, and its equivalent, the Red Peak Member of the Chugwater Formation) have been dated as Early Triassic. The stratigraphically higher redbeds of the Ankareh Formation and its equivalent, the Popo Agie Member of the Chugwater Formation, have been tentatively dated as Late Triassic by Love (1948) and Kummel (1950), but the actual age could range from Early to Late Triassic.

The overthrust belt consists of a series of very continuous subparallel lowangle overthrusts and tight, but generally cylindrical, folds contained in a zone approximately 100 kilometers in width. Thrusting is related to the Laramide orogeny as movement in this area ranges from the Late Jurassic to Early Eocene in age (Armstrong and Oriel, 1965). The thrust-fold belt possesses a characteristic eastern vergence with the ages of thrusting becoming younger to the east. The individual thrust plates have a maximum thickness estimated at about $7.5 \mathrm{~km}$ and consist of variable sections of the local miogeosynclinal sedimentary column of approximately $23 \mathrm{~km}$ of Cambrian through Tertiary sediment (Rubey and Hubbert, 1959). Figure 2 illustrates east--west cross-sections through the area of study.

Overthrust belts in North America are generally continuous belts of deformation on the foreland side of an ancient geosyncline or continental margin situation (Coney, 1973). Evidence also suggests that the overthrusts intrinsically derive their origin from the deformation of the miogeosynclinal sediments during orogenic activity. The destruction of the miogeosyncline in the area of the western Wyoming salient (Fig. 1) began with the uplift of a portion of eastern Idaho (a section of the Cordilleran geanticline of Eardley, 1962) and related subsidence in western Wyoming (Armstrong and Oriel, 1965; Crosby, 1968). This supports the theory that gravity sliding was in large part the mechanism for the Laramide overthrusting, or at least facilitated it in western Wyoming and elsewhere (Rubey and Hubbert, 1959; 


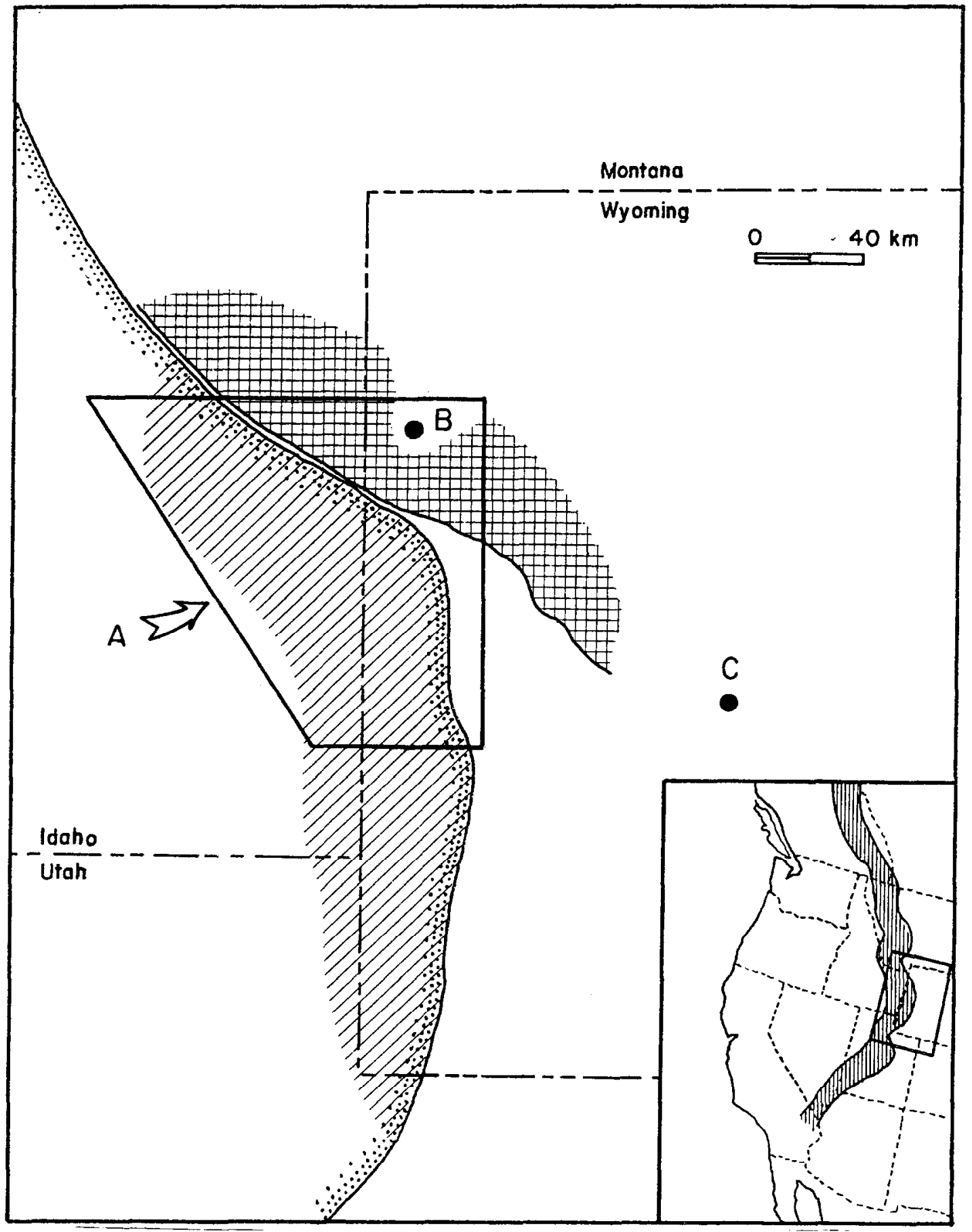

Fig. 1. Map of western Wyoming and eastern Idaho with the investigation area (A) and the stable foreland control sites (B, Slide Lake; C, Lander (two sites)). The stippled margin is the general transition between the miogeosyncline and the continental foreland; the diagonal striping is the well exposed area of the Idaho-Wyoming overthrust belt; the southwestern portion of the ancestral Teton-Gros Ventre-Wind River uplift is cross hatched, and the vertical striping (insert) is the Cordilleran overthrust belt of western North America (modified after Eardley, 1962). 


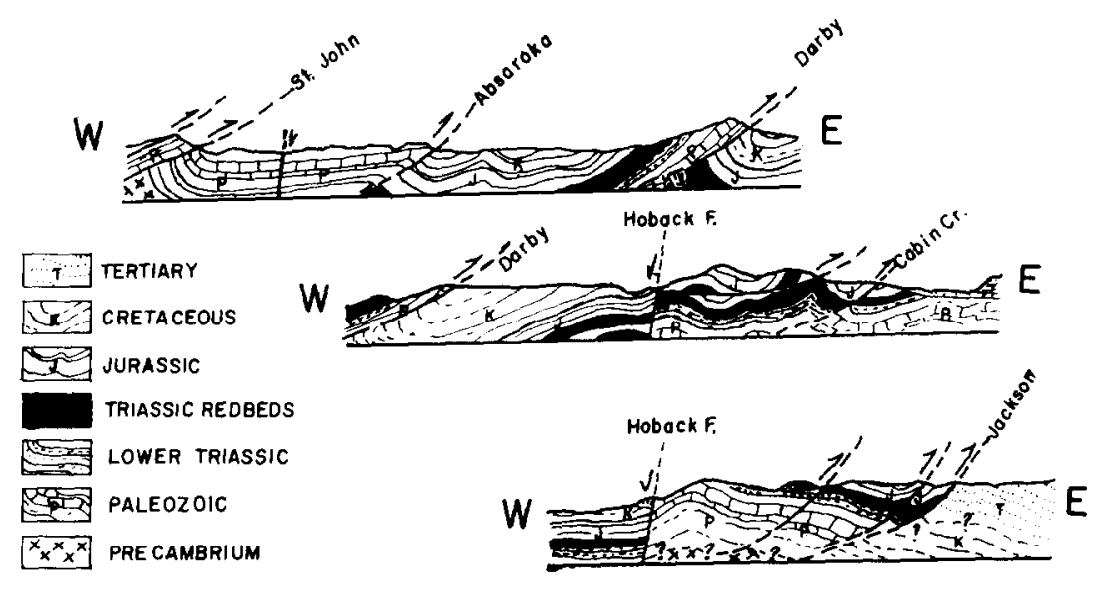

Fig. 2. Cross-sections across the Wyoming overthrust belt after Eardley (1962).

Armstrong and Oriel, 1965; Crosby, 1968; Price and Mountjoy, 1970).

A striking feature of overthrust belts is their sinuous nature, which seems related to the salients and reentrants along the margin of the ancient continental foreland. The Idaho-Wyoming overthrust belt is an excellent example of such a relationship, whereby the geometry of the western Wyoming salient of the North American craton is similar to that of the thrust-fold belt. In general, though, the 45-70 degree curvature in western Wyoming could be explained through several modes of overthrust emplacement:

(a) The frontal edge of the allochthonous sheet was originally arcuate and rotations need not occur to achieve a curvature of the thrust belt (Fig. 3A).

(b) Displacement of the thrusts was differential from north to south. The northern sections of the thrusts underwent less eastern displacement than the southern sections. This mechanism might produce small amounts of rotation, as well as transcurrent offsets within the plates (Fig. 3B).

(c) The overthrust sheets were shed radially off a rising highland. Little or no tectonic horizontal rotation would occur (Fig. 3C).

(d) Divergent emplacement occurred due to the interference with the thrust sheet movements by the foreland hinge. Tectonic rotations would occur roughly coincident with the structural trends and the configuration of the foreland hinge (Fig. 3D).

(e,f) Post-thrusting block rotation or oroclinal bending (Carey, 1955) occurred. Horizontal tectonic rotations of the thrusts would be observed in this case (Fig. 3E,F).

Of these hypotheses, most authors agree with either (c) or (d). Postthrusting block rotation (e,f) cannot be ruled out, though there is little evidence to support such concepts in this area. Crosby (1968) proposes that overthrusting in the western Wyoming salient was "radial and divergent across the salient" (c), while Rubey and Hubbert (1959) and Dorr et al. (in 


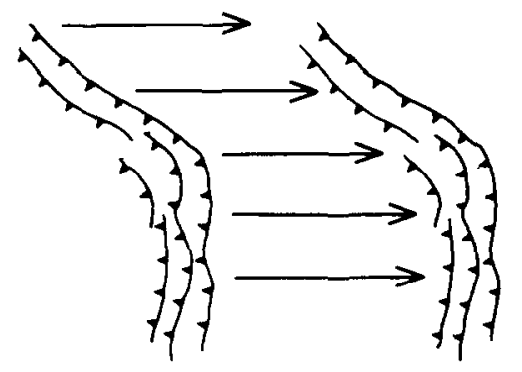

A

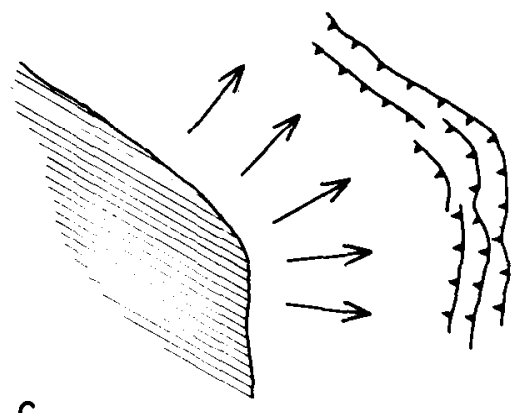

C

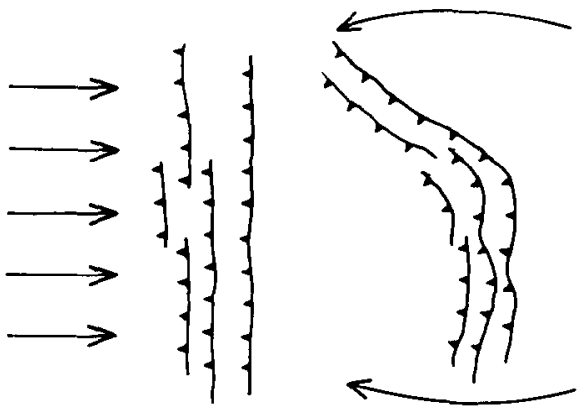

$E$

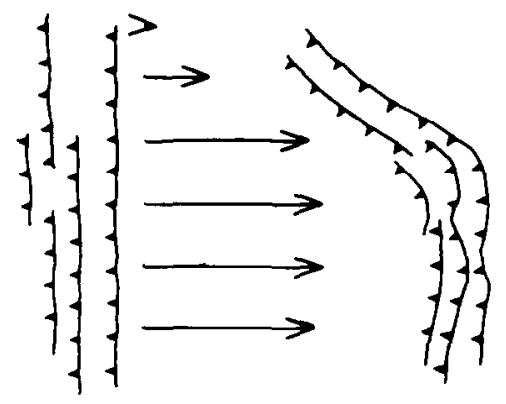

B
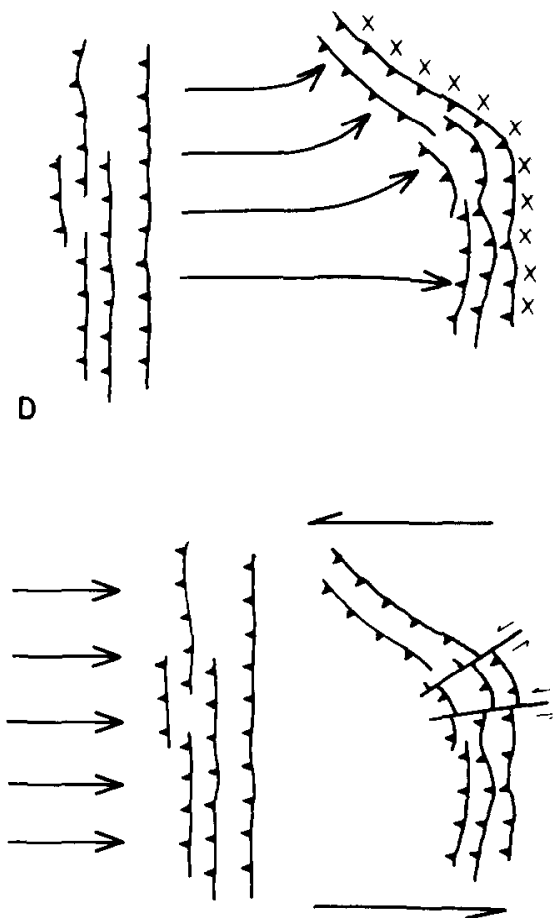

$F$

Fig. 3. Possible modes of overthrust emplacement leading to formation of an arcuate overthrust belt. A. An originally arcuate frontal edge is thrust eastward forming an arcuate overthrust belt. B. Differential amounts of displacement occurred between the northern sections and southern sections of the overthrust sheets. C. Radial emplacement off a rising highland. D. Divergent emplacement due to constraining effects of the foreland margin and other topographic features. $E$ and $F$. Post thrusting oroclinal bending $(E)$ or block rotation (F). Rotation of the paleomagnetic declination in sediments of the overthrust sheets would be well developed in D, E, or F. 
press) suggested that edge effects were a major influence on the direction of movement (d).

Paleomagnetic data from sites within the zone of overthrusting could be expected to reveal any rotations that have occurred and thus test the validity of the various hypotheses for the origin of the curvature.

\section{METHODS OF RESEARCH}

140 paleomagnetic samples were obtained from fifteen sites selected within the zone of overthrusting in order to determine possible rotations of a majority of the thrust sheets. In addition, 53 samples were obtained from three sites on the adjacent relatively stable foreland to provide undisturbed Triassic paleomagnetic directions. Of the sites within the overthrust belt, thirteen ( 120 samples) were sampled in the red sandstones and siltstones of the Ankareh Formation (Late Triassic?) and two sites (20 samples) in the Woodside Formation (Early Triassic) of similar composition. Of the relatively undisturbed sites, one ( 28 samples) was situated in the Ankareh Formation, one (10 samples) was in the Popo Agie Member of the Chugwater Formation (approximate age equivalent to the Ankareh Formation (Love, 1948; Wanless et al.,1955), and one (15 samples) in the Red Peak Member of the Chugwater Formation (age equivalent to the Woodside, according to Kummel, 1950). The number of samples collected per site ranged from 5 to 28 . A majority of the samples was collected with a portable drilling apparatus; the rest were collected as hand-samples. Generally, each sample was obtained from a different horizon, in order to achieve maximum stratigraphic distribution of samples at a site.

The samples consisted of red sandstones and siltstones with the magnetic carrier being primarily fine-grained hematite according to Picard (1964) who published the first paleomagnetic study of the Triassic redbeds in Wyoming. Though Picard did not undertake complete demagnetization studies, his results indicated that the magnetic directions in the Triassic sandstones and siltstones of the previously mentioned formations are fairly consistent over large distances. This fact validates the comparison we later make between the cratonic sites and the sites within the zone of thrusting.

The directions and intensities of the samples were measured using a Schonstedt SSM-1A spinner magnetometer and a Superconducting Technology cryogenic magnetometer. The natural remanent magnetizations (N.R.M.'s) had intensities that ranged between $4.0 \cdot 10^{-5} \mathrm{emu} / \mathrm{cm}^{3}$ and $1.0 \cdot 10^{-5}$ $\mathrm{emu} / \mathrm{cm}^{3}$. Progressive A.C. demagnetization up to 1000 Oe was carried out on several samples, but no noticeable decay was observed. Consequently, complete or partial progressive thermal demagnetizations up to $673^{\circ} \mathrm{C}$ were performed on the entire collection, and they revealed that the N.R.M. often consisted of two components: (1) a very small secondary component approximately coincident with the present-day field; and (2) a dominant component that compares favorably with the expected Triassic direction for 

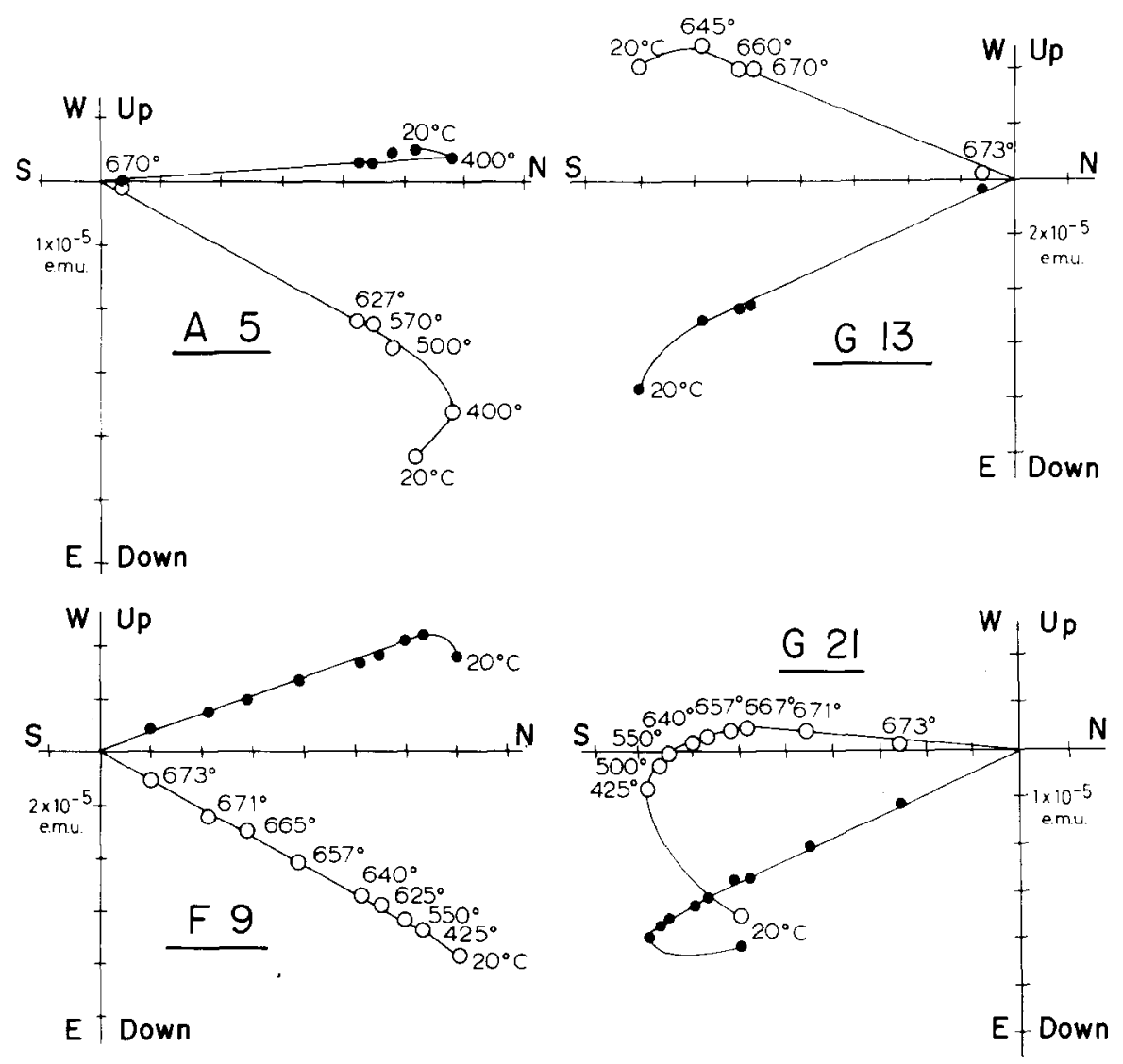

Fig. 4. Diagrams of progressive thermal demagnetizations of four samples characteristic of the red sediments obtained in this study (sites A, F, and G, Fig. 8). Plotted points represent successive positions - in orthogonal projection - of the end point of the magnetic vector. Full symbols represent projections on the horizontal plane; open symbols represent projections on the vertical plane. Numbers denote temperatures in degrees centigrade.

North America (Van der Voo and French, 1974). This primary component is revealed above $500^{\circ} \mathrm{C}$ as shown in a few typical demagnetization diagrams (Fig. 4).

\section{PALEOMAGNETIC RESULTS}

Acceptability of the results was judged by the directional stability of the characteristic component of the magnetization for each sample (Zijderveld, 1967) and by the degree of scattering of the final directions for each site. For example, sites with a cone of confidence of $95 \%$ probability greater than $30^{\circ}$ would be rejected. $20 \%$ of the samples, including one entire site (Q) did not meet these standards, as the directions of the magnetization did not sta- 
bilize during thermal demagnetization, but behaved erratically. Site $Q$ was rejected, moreover, because the primary component of the magnetizations of the samples at this site was obscured by a large secondary magnetization and thus was difficult to determine accurately.

On the whole the scatter of individual directions at each site was small, giving very acceptable Fisher parameters and final directions (Table I). The in-situ directions were corrected for the dip of the strata, by rotations about the strike. Since most of the folding is cylindrical no significant errors are to be expected because of this procedure. Figure 5 shows equal-area projections of typical sites within this collection. The $\alpha_{95}$ 's for the seventeen acceptable sites range between 4 and 16 degrees (65\% of the sites are under 10 degrees). The Fisher parameters, site locations, final directions, computed pole positions, and ages are listed in Tables I and II.

Reversals were commonly encountered in this collection with four normal,
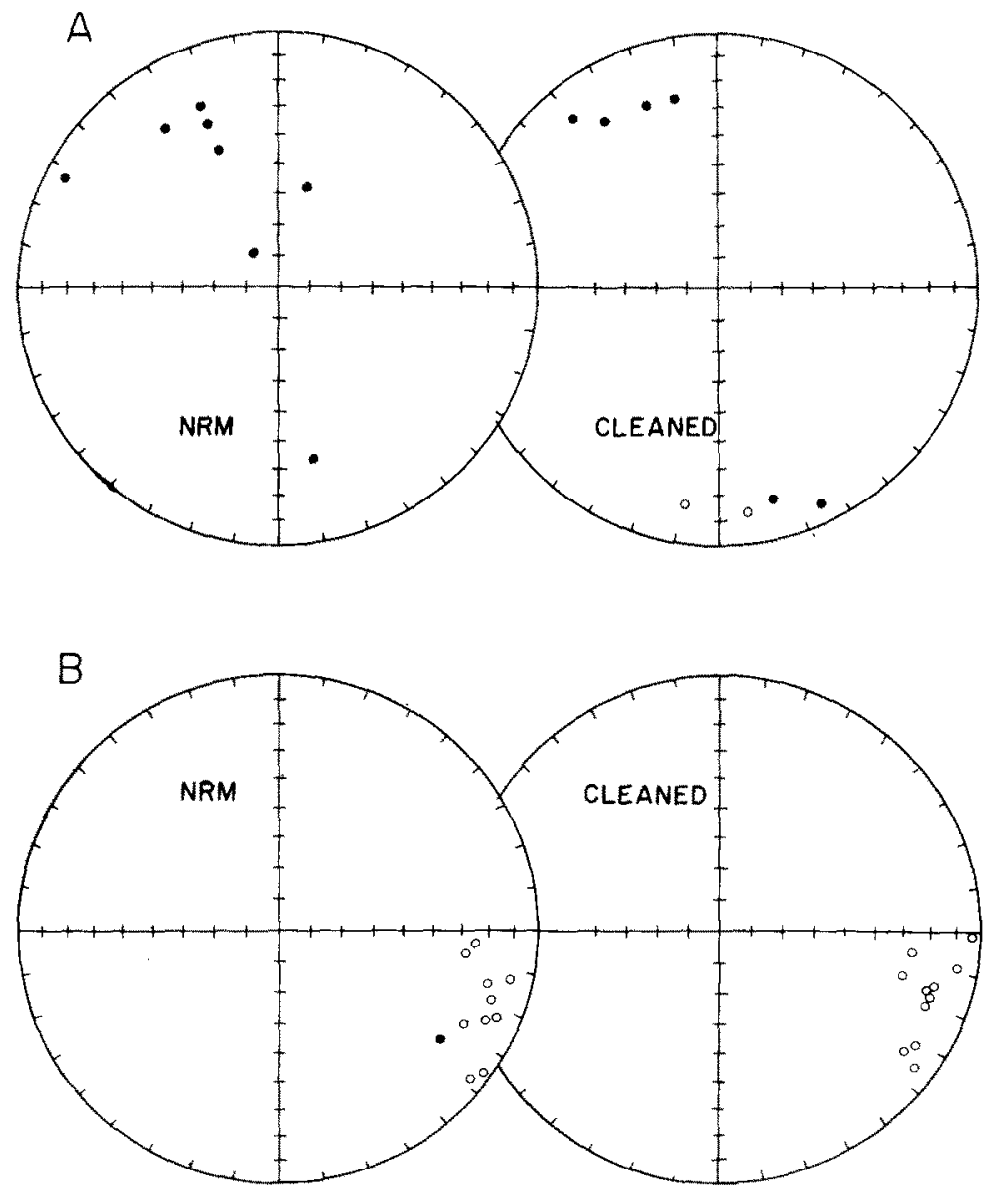

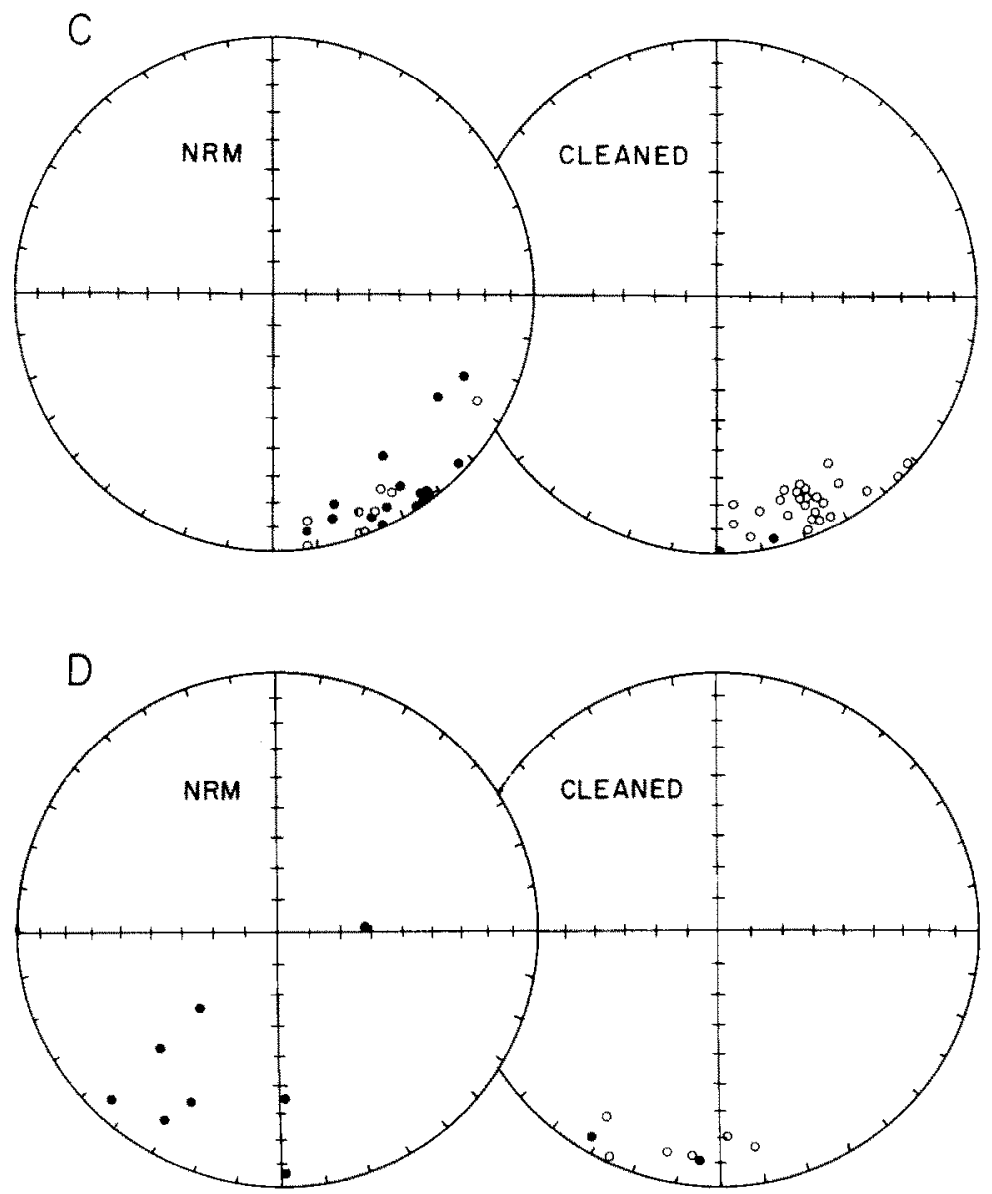

Fig. 5 A-D. Equal-area projections showing the directions of the magnetic vectors, before and after thermal demagnetization (cleaning), of four sites (C, T, G, H). Closed (open) symbols represent lower (upper) hemisphere projections (for locations see Fig. 8).

six reversed, and seven mixed-polarity sites. The mean directions obtained from all sites are shown in equal-area projection in Fig. 6. To facilitate comparisons between sites and the local Triassic control directions, reversed directions of each site were plotted in Fig. 6, regardless of their observed polarity. The computed $\alpha_{95}$ 's are shown for several sites as ovals on the projection. It is immediately apparent that the directions show a large variation in declination, but not in inclination. The mean declinations of the sites in the north, $\mathrm{V}, \mathrm{T}, \mathrm{S}$, and $\mathrm{X}$, are not compatible with the expected local Triassic declinations obtained from the undisturbed sites or from the other Triassic results of North America. They could be explained, however, by horizontal counterclockwise rotations of the thrust sheets ranging from 30 to 60 degrees. In contrast, the mean declinations of two sites in the south, $\mathrm{B}$ and $\mathrm{H}$ 


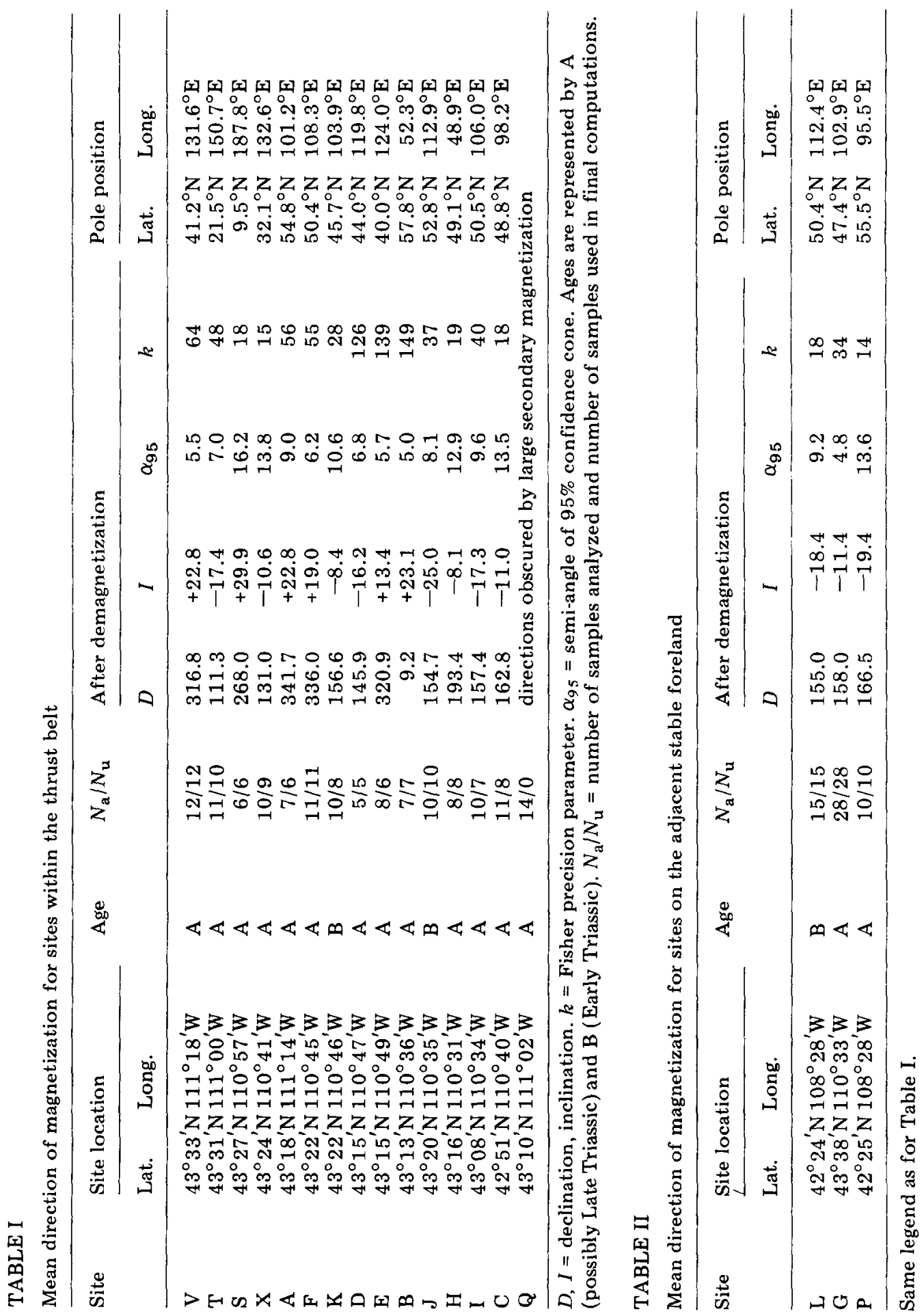




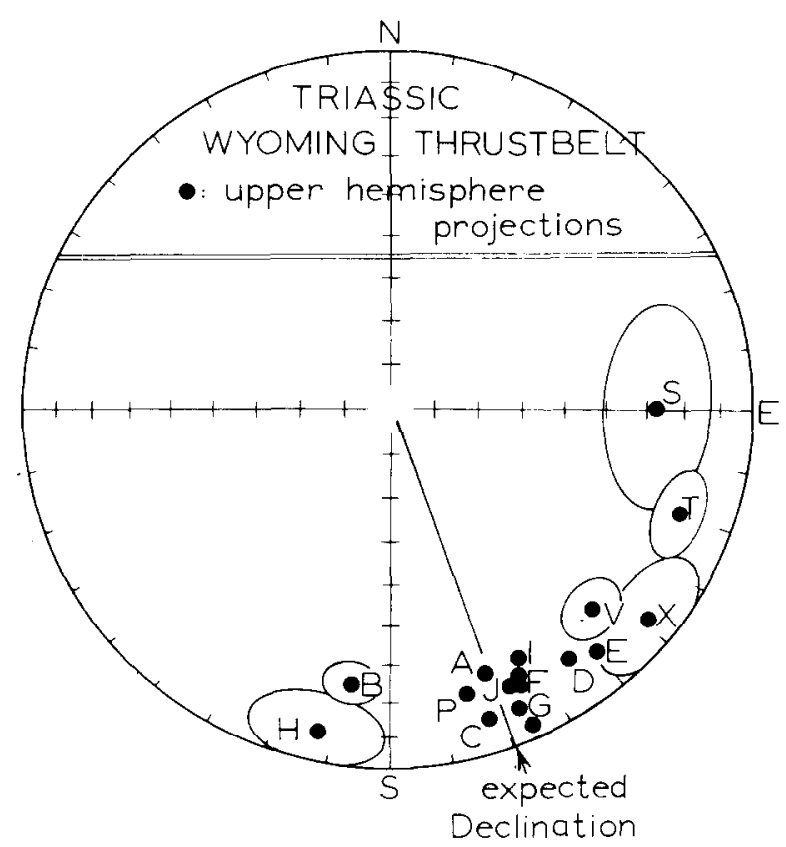

Fig. 6. Equal-area projection of mean site magnetic vectors of this investigation after thermal demagnetization. The ovals are cones of $95 \%$ confidence for some sites. Expected declination is that of a mean Triassic value for cratonic North America.

cannot be explained unless they have undergone clockwise rotations up to 30 degrees. The mean declinations of the sites within the central or bend area show small degrees of counterclockwise rotation, though in most cases they are not statistically different from the Triassic mean.

On the other hand, the inclination values of the thrust belt sites agree reasonably well with the expected local value. A plot of computed poles of all sites within the zone of overthrusting, together with previously published Permian and Triassic poles from the North American craton is shown in Fig. 7. It reveals that a small circle band about a pole located in the Wyoming area, about 10 degrees in width, contains almost all poles from the overthrust belt. This clearly indicates that systematic horizontal rotations of the paleomagnetic directions (and thus of the thrust sheets) readily explain the anomalous declinations of various parts of the overthrust belt.

The three control sites sampled in the Triassic sediments of the adjacent stable foreland gave very satisfactory results (Table II). The northern site (G) was obtained from the Ankareh Formation in a well developed section adjacent to Lower Slide Lake at the north end of the Gros Ventre Range (B in Fig. 1). The other two sites were sampled from Red Valley at the south end of the Wind River Range, west of Lander, Wyoming ( $C$ in Fig. 1). One 


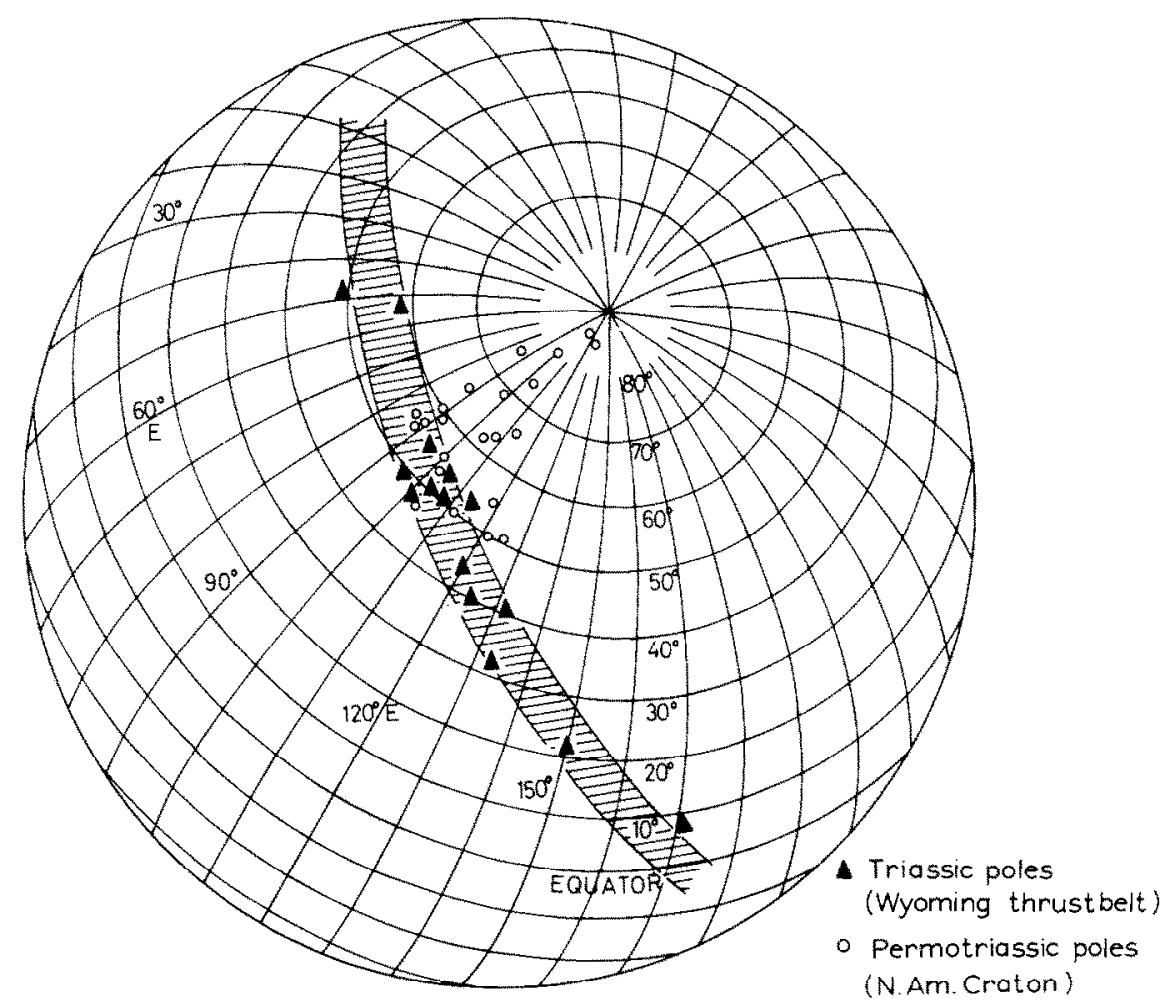

Fig. 7. Plot of paleomagnetic pole positions, obtained from the Idaho-Wyoming overthrust belt (triangles), and previously published reliable North American poles (open circles; Van der Voo and French, 1974). The shaded region is a small circle band around the Wyoming location approximately $10^{\circ}$ in width.

was in the Popo Agie Member (Late Triassic?) of the Chugwater Formation and the other site was obtained in the Red Peak Member (Early Triassic) of the Chugwater Formation. Previous studies of Triassic red sediments in this area (Collinson and Runcorn, 1960; Picard, 1964) were of N.R.M. directions only, although Picard performed some pilot demagnetizations. Table II gives Triassic poles that compare favorably in longitude with published Triassic poles of the North American continent, but they have shallow latitude values. In fact the poles are very close to the Late Permian poles for North America. This can be ascribed to inclinations shallow by approximately 10 to 20 degrees when compared to published Late Triassic results of cratonic North America (Van der Voo and French, 1974). This discrepancy may be due to the presence of an inclination error or possibly to an incorrect age assignment for the Ankareh and Popo Agie redbeds, as discussed in the introduction. 


\section{DISCUSSION}

The data obtained from this study of the overthrust belt indicate that the overthrust plates have undergone systematic tectonic rotations in the horizontal plane probably while forming the structural arc in the belt near Jackson, Wyoming (Fig. 8). The relative rotation between the northern and the southern regions exceeds 80 degrees in the easternmost (frontal) thrust. The shift in paleomagnetic declination along the arc suggests that the paleomag-

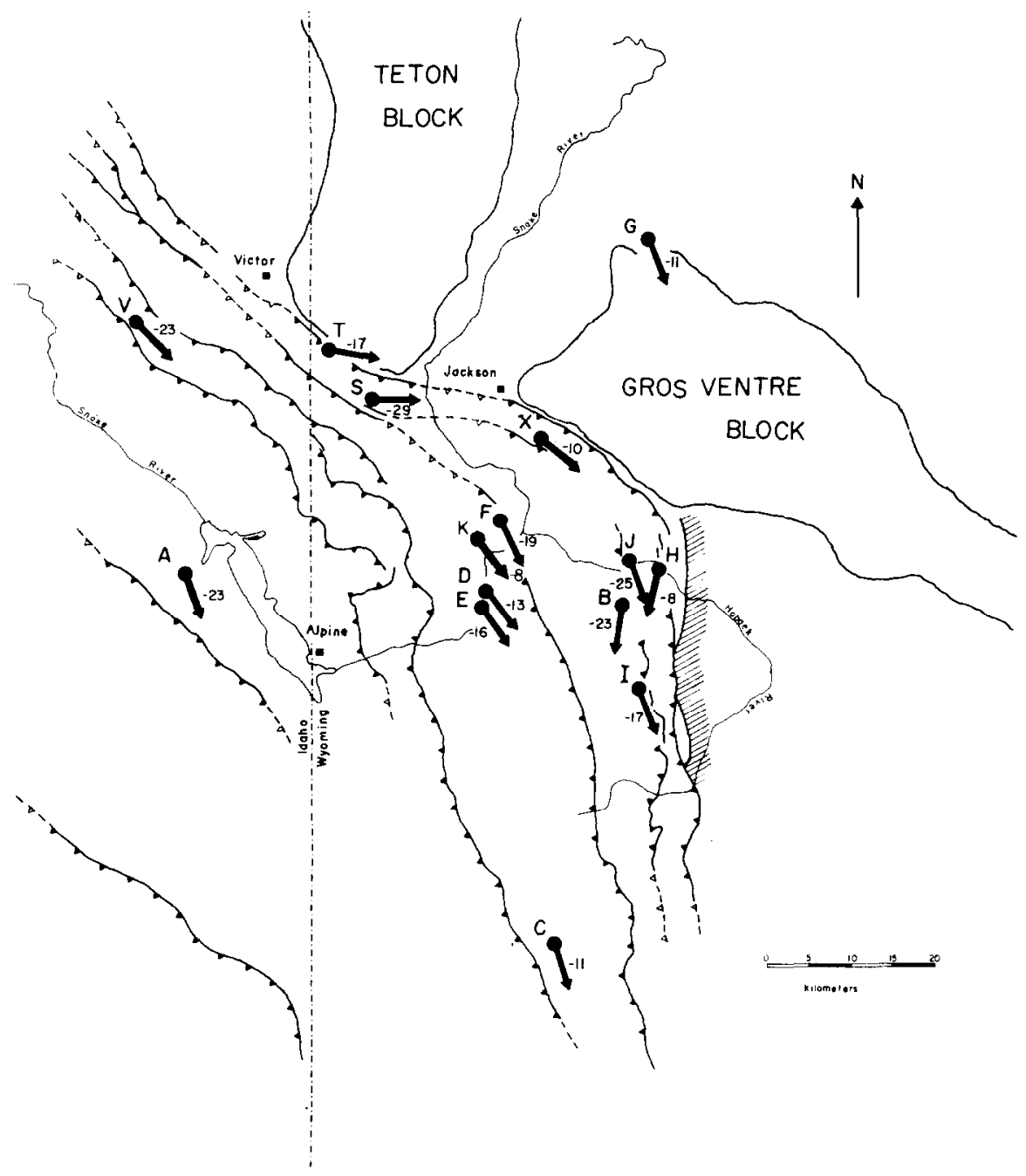

Fig. 8. Map of the investigation area showing major tectonic features. The closed circles are the site locations. Arrows represent the mean site declination, whereas the number is the inclination value. The diagonally shaded region is the upthrown side of the Game Hill reverse fault (modified after Dorr et al. (in press) and Schroeder (1969)). 
netic rotations are coincident with the shift in strike of the structural trends. Upon close examination, the paleomagnetic rotations seem responsive even to the orientation shifts of smaller-scale structures, though here the statistical uncertainties do not allow more than tentative conclusions. Hypotheses for the rotations of the thrust sheets and the origin of the structural bend have been discussed in the introduction. The occurrence of the rotations to the large degree reported in this paper eliminates several hypotheses, specifically originally arcuate source area (Fig. 3A), differential sliding (Fig. 3B), and also the radial divergence hypothesis of Crosby (1968; Fig. 3C). An explanation for the bend involving oroclinal bending (Carey, 1955; Fig. 3E) or block rotation (Fig. $3 \mathrm{~F}$ ) cannot be eliminated, but these explanations are unlikely as there is little supporting geological evidence for basement involvement, and the paleomagnetic declinations show an increasing amount of rotation from west to east which would be unlikely to occur in either of these cases. The deviation of the mean declination is increasing toward the east, with the easternmost Prospect-Cliff Creek-Jackson thrust sheet (Figs. 2 and 8 ) showing the greatest degree of rotation. This fact is also apparent in the geometry of the thrust-fold belt, the easternmost thrust traces showing greater shifts in orientation. It lends support to the idea that the elevated foreland margin was a major constraining influence on the rate and direction of thrusting; thus, as thrusting progressed eastward, the frontal edges of the overthrust sheets would tend to assume the configuration of the foreland hinge, through the mechanism of horizontal rotations.

The easternmost, generally youngest, thrusts, being closest to the foreland margin, show the greatest rotational effect. The ancient elevation and configuration of the foreland margin in western Wyoming is well documented, with many authors agreeing on the location and arcuate shape (Rubey and Hubbert, 1959; Eardley, 1960, 1962; Armstrong and Oriel, 1965; Dorr et al., in press). Furthermore, Love et al. (1973) provide evidence that early in the period of thrusting the incipient Teton-Gros Ventre Precambrian block began to rise in the northwest of Wyoming and by latest Cretaceous had formed a large northwest-southeast trending positive (constraining) feature. In addition, Dorr et al. (in press) argue that the Game Hill high-angle reverse fault (location shown in Fig. 8) became active in the Early Palcocene, thus forming a north-south trending constraining feature that was present during the time of movement of the easternmost thrust sheet (Prospect-Cliff CreekJackson). The Game Hill fault is said by Dorr et al. (in press) to have interfered with the movement of the Cliff Creek thrust.

Positive correlation between the edge effects and the nature of thrust movement is discussed by Rubey and Hubbert (1959) and Kehle (1970). They pointed out that constraining features affect not only the rate of movement., but also the direction of movement. We conclude that the existence of an arcuate foreland margin and the presence of such constraining features as those discussed previously can provide the restrictive influences that cause overthrust sheets to rotate. 


\section{ACKNOWLEDGEMENTS}

We wish to express our indebtedness to the preliminary studies done by Tom Crough, now at Stanford University. Special thanks go to Professors H. Pollack and J.A. Dorr, Jr. for their constructive comments on the manuscript. Professor Dorr also provided invaluable knowledge and advice on the area of study.

\section{REFERENCES}

Armstrong, F.C. and Oriel, S.S., 1965. Tectonic development of Idaho-Wyoming thrust belt. Bull. Am. Assoc. Pet. Geol., 49: 1847-1866.

Carey, S.W., 1955. The orocline concept in geotectonics. Proc. R. Soc. Tasmania, 89: $255-288$.

Collinson, D.W. and Runcorn, S.K., 1960. Polar wandering and continental drift: evidence from paleomagnetic observations in the United States. Bull. Geol. Soc. Am., 71: 915-958.

Concy, P.J., 1973. Plate tectonics of marginal foreland thrust-fold belts. Geology, 1 (3): $131-134$.

Crosby, G.W., 1968. Vertical movements and isostasy in the western Wyoming overthrust belt. Bull. Am. Assoc. Pet. Geol., 52: 2000-2015.

Dorr, J.A., Jr., Spearing, D.R. and Steidtmann, J.R., in press. Geologic history of the Hoback-northern Green River basin and adjacent ranges in central western Wyoming. Geol. Soc. Am. Spec. Pap.

Eardley, A.J., 1960. Phases of orogeny in the fold belt of western Wyoming and southeastern Idaho. In: Overthrust belt of southwestern Wyoming and adjacent areas. Wyo. Geol. Assoc. 15th Ann. Field Conf. Guidebook; p. 37-40.

Eardley, A.J., 1962. Structural Geology of North America. Harper and Row, New York, $743 \mathrm{pp}$.

Kehle, R.O., 1970. Analysis of gravity sliding and orogenic translation. Bull. Geol. Soc. Am., 81: 1641-1664.

Kummel, B., 1950. Triassic stratigraphy of the area around the Green River basin, Wyoming. In: Wyo. Geol. Assoc. 5th Ann. Field Conf. Guidebook; p. 28-36.

Love, J.D., 1948. Mesozoic stratigraphy of the Wind River basin, central Wyoming. In: Wyo. Geol. Assoc. 3rd Ann. Field Conf. Guidebook; p. 96-111.

Love, J.D., Reed, J.C., Jr., Christiansen, R.L. and Stacey, J.R., 1973. Geologic block diagram and tectonic history of the Teton region, Wyoming-Idaho. U.S.G.S. Misc. Geol. Invest., Map I-730.

Picard, M.D., 1964. Paleomagnetic correlation of units within the Chugwater (Triassic) Formation, west-central Wyoming. Bull. Am. Assoc. Pet. Geol., 48: 269-291.

Price, R.A. and Mountjoy, E.W., 1970. Geologic structure of the Canadian Rocky Mountains between Bow and Athabasca rivers - a progress report. Geol. Assoc. Can., Spec. Pap., 6: 7-25.

Rubey, W.W. and Hubbert, M.K., 1959. Role of fluid pressure in the mechanics of overthrust faulting, II. Bull. Geol. Soc. Am., 70: 167-206.

Schroeder, M.L., 1969. Geologic map of the Teton Pass quadrangle, Teton Co., Wyoming, U.S.G.S., Washington, D.C.

Van der Voo, R. and French, R.B., 1974. Apparent polar wandering for the Atlanticbordering continents: Late Carboniferous to Eocene. Earth Sci. Rev., 10: 99-119.

Wanless, H.R., Belknap, R.L. and Foster, H., 1955. Paleozoic and Mesozoic rocks of the 
Gros Ventre, Teton, Hoback, and Snake River Ranges, Wyoming. Geol. Soc. Am. Mem., 63: 90 pp., 13 pl.

Zijderveld, J.D.A., 1967. A. c. demagnetization of rocks: analysis of results. In: D.W. Collinson, K.M. Creer and S.K. Runcorn (Editors), Methods of Paleomagnetism. Elsevier, Amsterdam; p. 254-286. 